\title{
AGRICULTURAL INSURANCE UNDER THE SOLVENCY II DIRECTIVE
}

\author{
Vladimir Njegomir ${ }^{1}$, Rajko Tepavac ${ }^{2}$, Miloje Obradovic ${ }^{3}$
}

\begin{abstract}
Summary
Solvency II Directive represents a new framework of unique solvency regulation of insurance and reinsurance companies in the European Union. Although it has not yet been implemented in national legislations, it can be concluded, based on the directive wording and conducted quantitative studies, that it will have implications on agricultural producers since they are the users of insurance services. The aim of the research presented in this paper is to analyse the implications of the new directive to agricultural producers since they are the insureds and the main actors of agribusiness. Firstly, the paper gives an overview of the basic features of the new regulatory framework and then it points at the issues and the needs for intensive application of Directive in order to improve the insurance business in Serbia. The process will direct the settlement of major claims, the ones that are typical of catastrophic risks in agriculture, towards the insurance, while the expectations from the government will be directed towards the regulation of the setting and economic measures (development and investment subsidies, cooperative movement). In addition, the paper points at the demands of the new regulation and analyses the implications of the new regulation regarding the settlement of claims resulting from major flood since it represents the example that proves the basic postulate.
\end{abstract}

Key words: insurance, agricultural producers, catastrophic floods, claims and prevention in agribusiness, risk management, reinsurance, Solvency II.

JEL: $G 22, Q 01$

1 Vladimir Njegomir, Ph.D., Assistant Professor, Faculty for Law and Business Studies Dr. Lazar Vrkatic, Bulevar oslobodjenja no. 76, 21000 Novi Sad, Serbia, Phone: +381 6413990 05, E-mail: vnjegomir@eunet.rs

2 Rajko Tepavac, Ph.D., Associate Professor, Business Academy, Cvećarska Street no. 2, 21000 Novi Sad and Dunav osiguranje, Makedonska Street no. 4, 11000 Belgrade, Serbia, Phone: +381 63200 910, Email: tepavac92@gmail.com

3 Miloje Obradović, Ph.D., Associate Professor, Faculty of Engineering Management, Belgrade, Faculty of Engineering Management, Bulevar Vojvode Mišića no. 43, 11000 Belgrade and Assembly of the City of Belgrade, City Government, 27. marta Street no. 43, 11000 Belgrade, Serbia, Phone: +381 1141404 20, E-mail: miloje.obradovic@fim.rs

EP 2014 (61) 3 (587-602) 


\section{Introduction}

Solvency implies long-term ability to settle all accrued liabilities, i.e. a solvent insurance company is the one which is capable in long-term to reimburse to the insured persons all damages, by their number and amounts, but also to meet all financial liabilities to government, employees, other insurance underwriters and re-insurance underwriters, to their maturity date (Njegomir, 2011b). Due to a fact that in insurance business, agricultural producers and other insured persons, owing to information asymmetry, are considered as a party which should be protected, the insurance regulation is inevitable. Taking into consideration that, by purchasing services of insurance cover, the agricultural producers basically buy a promise of future payment, a regulation of obligingness of solvency, as one of the basic economic principles of the insurance companies business, imposes as a necessity. If an insurance company would become insolvent, the agricultural producers would go through a financial insecurity, and would appear some social and economic costs, but the most important is that crops and fruits insurance, as well as other insurances, due to impossibility to insurance indemnity, would lose its meaning of existence and, from the agricultural producers point of view, it represents a protection of production risks. Also, the public confidence in insurance would be diminished or lost, which would manifest in decreasing demand for the insurance, while a negative impact of the loss would experience the insurance companies in Serbia during nineties of the $20^{\text {th }}$ Century and the first few years of this century. Taking into consideration, in all managerial and business activities of the insurance companies, especially in activities of accepting the risk, provisioning of the insurance companies, risk transfer in re-insurance and investments, it is necessary to permanently reconsider a relation between a risk and a capital, at the aggregate level, in order to provide a continuous preservation of solvency position (Njegomir, 2006).

On the European Union level, at the moment, a current framework of solvency regulation (Solvency I) is in an alteration phase. Namely, directive Solvency II was adopted in 2009 and the directive's apply was initially anticipated for the year 2012. This directive represents a new regulatory framework, which will be of importance for the EU countries, as well as its future members, including Serbia. Taking into consideration a significance of insurance market within the EU member countries, Solvency II has already significant implications on solvency regulation in other countries, including especially Switzerland, Bermuda Islands and Japan. It follows the significance of researches carried out in the paper, which goal is to present implications review of new regulatory rules for the agricultural producers insurance. In the paper, we point out, at first, to basic requirements of the new regulatory rules and then their key implications.

\section{Quantitative requirements Solvency II}

The access provided by Solvency II regulatory framework and Swiss Solvency Test is the most acceptable form of regulation of the insurance companies activities, especially if there a need of financial groups regulation is taken into consideration, in regard that the countries which had provided such supervision, had no need to intervene aiming to save an insurance underwriter or an re-insurance underwriter, taking into consideration also problems of 
the insurance group American International Group (Njegomir, 2011a). The Solvency II regulatory framework bases on three pillars (Njegomir, 2009) as we can see in picture 1. The first pillar represents quantitative requirements and the second and the third one are qualitative requirements. Possibility of using the three pillars structure, for regulation of insurance industry solvency as in Basel II, was implied in 2002 (EC and KPMG, 2002) and was adopted in March 2003 (EC, 2003).

Picture 1. Structure of Solvency II of regulatory framework based on three pillars

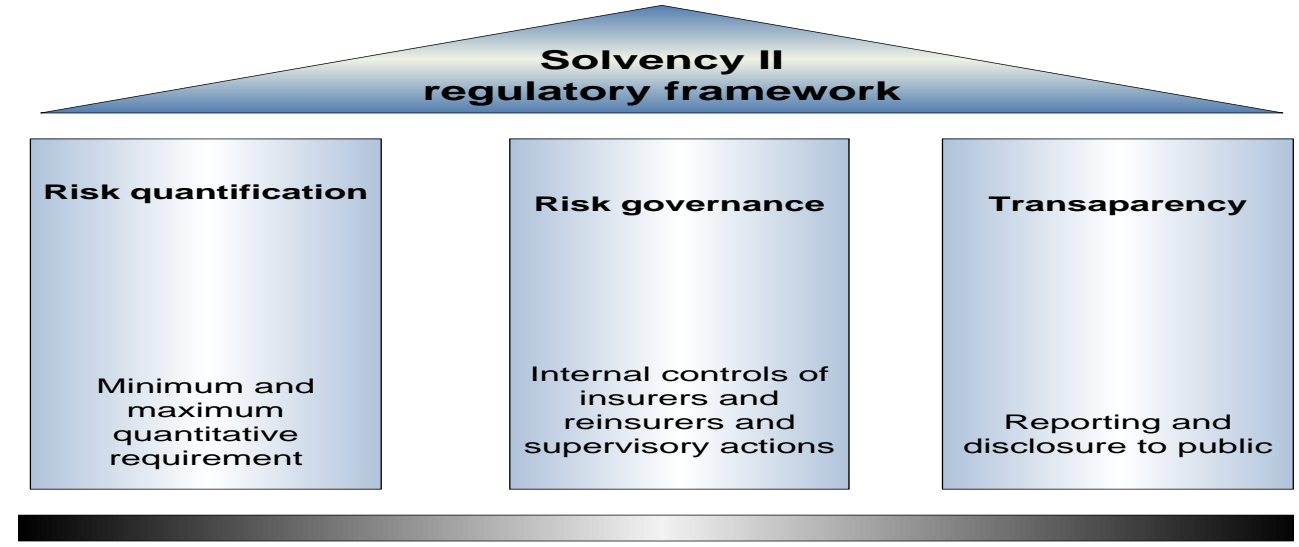

Source: Njegomir, 2009.

Regulatory determination of theoretical level of solvency determines also the solvency position of insurance companies in a specific legal system. Taking it into consideration, as a solvent insurance company can be considered the one which assets are higher than the theoretical solvency level, most often determined as a minimum and target capital requirement. A basic goal of capital requirements determination is establishment of a certain control level, which serves as a base for supervision of an insurance underwriter, aiming to protect an insured person, in case of agricultural insurances - agricultural producers. A control level can be determined in form of one or several capital requirements, for example, in form of a minimum and available capital requirement.

The available capital of an insurance or re-insurance company represents a difference between assets and liabilities, i.e. a market value of total assets and technical reserves (Picture 2), where, generally observed, a company is solvent if available capital is higher than zero, i.e. if there is a surplus of assets over the liabilities of a company. On the contrary, insolvency is a situation in which the available capital (AC) is less than zero, i.e. if the liabilities are higher than the total assets of a company. The solvency of insurance or re-insurance company is of essential significance for every agricultural producer and therefore for the total agricultural production. High quality of repair occurred in agriculture, typical by a small coefficient of capital turnover, provides a basic safety to an agricultural producer that his season has been saved and that the assumptions for the next production cycle have been made. Before we point out to differences in the level of the claimed capital, we emphasize that Solvency II regulatory framework has been based on the market evaluation of assets and liabilities, 
unlike the existing regulatory framework which bases on accounting evaluation. There a fair value of assets and liabilities is represented, which generally implies a market value or its approximation. Expressing the assets position by the market value is not a problem, but it is for calculating the liabilities, especially in property insurance in agriculture, regarding that there is no market for liabilities of insurance and reinsurance companies, and thereby their market value. The positions of assets by activities types, where agro-sector makes one third of value, in registers of insurance companies concentrate by sub-systems, but a functional relation within a sub-system (e.g. agriculture, construction, etc.) is of the same principle as a macro-total level. With this in mind in assessing the value of liabilities of insurance and reinsurance companies use the concept of best estimate to which is added the risk margin, which represents the market value. The best assessment is defined and calculated as a net present value of future cash flows of insurance portfolio, where uses a risk-free rate of interest. For this reason adds a risk margin to a sum of the best evaluation of liabilities (Picture 2). The risk margin represents a cost of capital necessary in every year until the liabilities expire. The risk margin essentially calculates to protect an insured person, as an additional security measure of insurance and re-insurance companies.

Picture 2. Minimum (MCR) and solvency capital requirement (SCR)

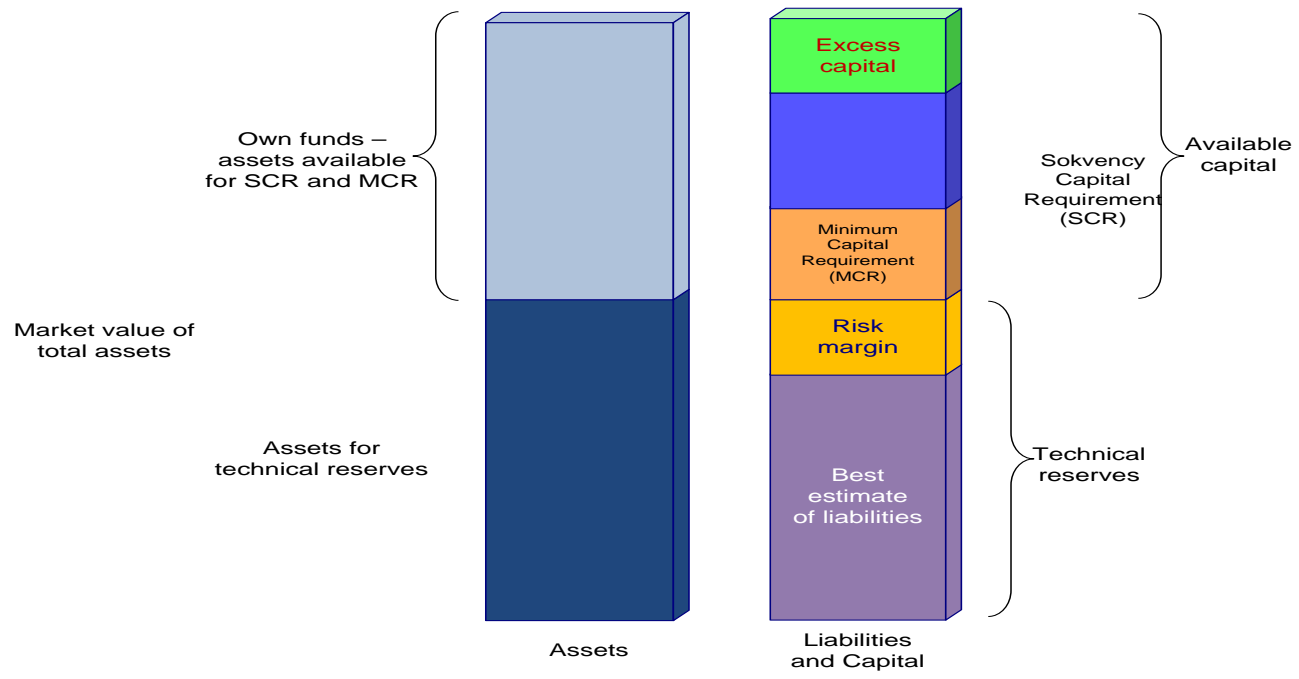

Source: Njegomir, 2009.

The Solvency II regulatory rules, by the first pillar, which refers to quantitative requirements anticipates the existence of two capital requirements, a minimum capital requirement (MCR) and a solvent capital requirement (SCR), (Njegomir, 2009). The minimum capital requirement is a level of capital which represents a base for intervention of supervisory authorities. That is to say, if an insurance underwriter or a re-insurance underwriter does not dispose with enough capital anticipated by this requirement, the supervisory authorities apply measures like prohibition of entering into new contracts on insurance or revoking a licence. The existence of available capital on the level of a minimum capital requirement in short-term can provide a continuity in business, along with the possibility of risk transfer or recapitalization. Major 
flood damages in May 2014 are a fact which confirms a need for risk transfer of catastrophic floods. Major damages surpass capital dimensions of an insurance underwriter and jeopardize his solvency, if the risk has not been split. As a premium pays in advance, non-payment to agriculture is, firstly, a great uncertainty for an insured person's expectations, for which he had insured, and secondly, insolvency of an insurance underwriter and loss of market and finally, high social and material costs in the field of agriculture (crop growing, livestock breeding, fruit growing, etc.) which must be compensated. In our case, the state's obligation to support agriculture appears cyclically as an imperative. Determination of the minimum capital requirements is determined in a similar way as in previous solvency regulations. The minimum capital requirement determines in an absolute amount, 2.2 million euro for every non-life insurance underwriters, i.e. 3.2 million euro in case that insurance underwriters deal also with auto-liability insurance businesses, responsibility for using aircrafts, responsibility for using crafts, general liability, credit and guarantee, 3.2 million euro for life insurers and 3.2 million euro for insurance underwriters, except a captive of a re-insurance underwriter for which has been determined the minimum capital requirement of one million euro.

Framework of method of applying a standard formula was given by the directive, where was determined that, in determination of a size of the solvent capital requirement, must be taken into consideration three elements: 1) basic solvent capital requirement in which determination must take into consideration non-life, life, health, market and credit risk, arising from the contractual obligations failing, 2) capital requirement for an operational risk, 3) correction for cover of unexpected losses, which can appear as a result of simultaneous decrease of technical reserves or deferred taxes or their combination. Calculation of the solvent capital can be expressed by the following formula:

$S C R=B S C R+S C R_{\text {op }}-A d j$

Where: $S C R$ - solvent capital requirement, $B S C R$ - basic solvent capital requirement, $S C R_{o p} S C R_{o p}$ - capital requirement for operational risk and Adj correction for covering possible losses, which can appear as a result of simultaneous decrease of technical reserves or deferred taxes or their combination (Njegomir, 2011c). In the stated formula, the basic solvent capital calculates as:

$$
B S C R=\sqrt{\sum_{i, j}{\operatorname{Corr} S C R_{i j}} x S C R_{i} x S C R_{j}}
$$

$\operatorname{CorrSCR_{ij}} \operatorname{CorrSCR_{ij}}$ is a correlation stencil, i j unfold by all possible values - for the risk of non-life, life, health insurances and market and credit risk (Njegomir, 2011c).

The solvent capital requirement (SCR) is a level of capital, which an insurance underwriter and an re-insurance underwriter should possess, aiming to provide solvency under normal circumstances, and which is sufficient for covering unusually harmful events, like by Solvency II directive was determined, the events which happen once in two hundred years. It is about a target solvent requirement which should reflect risk of an insurance 
or reinsurance company and as additional capital, above the level of minimum capital requirement, to ensure the unexpected losses cover. While determining the SCR should take into consideration all risks by which an insurance company has been exposed, i.e. insurance risks, market, credit and operational. Determination of the SCR amount bases on the principles which should illustrate economic reality of insurance and reinsurance companies business and which only point out desirable results, where assets for their achievements, a standard formula, an internal model or their combination, represent a subject of their free choice, with necessity of supervisory authority's approval. A measure which uses for determination of the SCR is VaR (Value at Risk), i.e. measure of value at risk, which determines for own funds of an insurance underwriter and a re-insurance underwriter on the confidence level of $99.5 \%$, during a one year period. The value at risk ( $\mathrm{VaR}$ ) is a measure which summary expresses the hardest loss during the target time period with provided level of reliability (Jorion, 2001). Determining the value measure in risk on the reliability level of $99.5 \%$ essentially means that the solvent capital requirement bases on a size of capital, which should be provided in order to insure that an insurance- or an re-insurance underwriter's bankruptcy does not occur more than once in 200 cases, i.e. that the companies will be able, with probability of at least $99.5 \%$, to fulfil their obligations to insured persons and insurance users in future 12 months.

\section{Qualitative requirements Solvency II}

The quantitative requirements is dedicated the most attention in regard to their significance for safety of an insured person. They are the most important for agricultural producers in regard that they directly guarantee the insurance indemnity, which is of crucial significance for continuity of agricultural production. However, the supervisory authorities will not implement monitoring of insurance and reinsurance companies adjustment only by checking the minimum and solvent capital requirement, but, as the clause 35 of the Directive (Directive 2009/138/EC) points out, also by evaluation of an insurance underwriter and an re-insurance underwriter's management system, activities they do, value principles which are applied in determination of solvency, risks they face, but also applied systems of risk governance, capital structure, needs and capital management. Also, by the clause 36 of the Directive, was determined to make an assessment of qualitative requirements in the supervision procedure, which refer to management system, risks assessment to which have been exposed the insurance and reinsurance companies or might have been exposed, and evaluation of ability of the companies, as subjects of supervision to assess risk-taking, taking into consideration the environment in which they do business. A control of any or sufficient insurance in agriculture is not present in Serbia, and as a first measure imposes an introduction of mandatory forms of insurance by activities or agricultural region or crop. Everything previously mentioned points out to a necessity of adequate understanding and adjustment of insurance and reinsurance companies business with the requirements of the second and the third pillar of Solvency II.

The second pillar represents the internal control and risk governance principles of an insurance underwriter and a re-insurance underwriter and principles on which determine 
a framework for supervision of the internal controls and management practice with risk and capital, and adequacy of the insurance and reinsurance companies' capital (Njegomir, 2009). Aiming to adjust to the requirements of a new solvency regulatory framework, the insurance and re-insurance companies will have to apply the management system, which will include all business activities. An adequate system of corporative management (especially with companies and husbandries in the field of agriculture, since service activities have far gone in applying this model) should include a transparent organizational structure with a clear distribution of tasks and responsibilities and an efficient support of information systems to all business activities. By the clause 42 of the Directive was determined that the insurance and reinsurance companies must provide that persons which manage with companies or have key roles, fulfil two conditions at any time: a) that their professional qualifications, knowledge and experience are adequate in order to provide a regular and wise management, and b) to have a good reputation and integrity. The process of risk governance was anticipated by the clause 44 of the Directive, which requires from an insurance underwriter and an reinsurance underwriter to have a set effective system of risk governance, which consists of strategies, processes and reporting procedures necessary for a continuous identification, measuring, monitoring, managing and reporting on risks, they have been exposed to, or might be exposed to, and their inter-dependences, on individual and group level. In case that an insurance underwriter and an re-insurance underwriter use also a partly or a complete internal model of management with risk and capital, this function should perform also the following additional tasks: a) design and implementation of an internal model, b) testing and validation of an internal model, c) documentation of an internal model and all its changes, d) analysis of an internal model performances and making reports, e) informing on managerial structures on an internal model performances, suggesting improvements and notices on the previous efforts for improvement of identified weaknesses.

An actuarial role was determined by the clause 48 of the Directive. It was primarily directed to apply of methodologies and procedures for evaluation of technical reserves adequacy, adequacy of accepted risks in insurance cover, as well as the adequacy of reinsurance program. Quality of risk assessment in agriculture is actuarially very difficult to comprehend, because there is no statistical series, neither by the type of product, nor the region, so a base for an exact estimate is not adequate. It remains to apply different underwriting skills, typical for an investment activity, which can anticipate endurance by the catastrophic damages risk. A basic goal is to provide a thoughtful capital allocation and to improve business decision-making by applying superior means of identification and modelling of risk. By the clause 46 was specified that insurance and reinsurance companies should have set effective system of internal control. The system should involve administrative and accounting procedures, the internal control framework, organized reporting at all levels of insurance or reinsurance companies and a process of meeting the regulatory requests. The role of internal revision was determined by the clause 47 of the Directive. Within this role should be involved the evaluation of adequacy and effectiveness of the internal control system, as well as other elements of management system. A basic request for successful functioning of internal revision is its independence. 
The third pillar of Solvency II often is called also „forgotten“ (PricewaterhouseCoopers, 2010), although we consider this pillar very important to agricultural producers, as service users of insurance cover. This pillar refers to the market discipline, which primarily realizes by reporting and disclosing information to supervisory authorities, but also to the general public. The information, as damages trend (risk increase) in some activities as agriculture, due to the climatic disturbances and determination of all risk insurance package against such risks, should place on the market by those who do it. A regulator should request the information. On the other side, potential insured persons have to present the type and amount of damage they bear, not knowing the different. In that way creates a complete image (statistical, financial, and social) on a need of some insurance type, as it is now typical the types of insurance in agriculture. There are two types of regular information disclosing, requested by the Solvency II, a report to the supervisory authorities and a report on solvency and financial condition. The report to the supervisory authorities should have all information necessary for business supervisory of insurance and reinsurance companies, both in quantitative and qualitative sense, in accordance with the regulations of the clause 35 of the Directive. The report on solvency and financial condition is meant for the general public and, in accordance to the clause 50 of the Directive, should contain both qualitative and quantitative report. The quantitative report, which will submit to the supervisory authorities and will have the greatest implications to the organizational resources, will consist of several forms - if it is about an individual insurance or reinsurance company, the reporting forms will be (PricewaterhouseCoopers, 2011): 1) balance sheet, 2) assets - investments, 3) solvent capital request, minimum capital request and own means, 4) technical reserves - life insurances, 5) technical reserves - non-life insurances, 6) analysis of variations, state and cover, and 7) re-insurance, while it is about a group - it will be needed also consolidated reports, risk concentrations and internal transactions. Besides the regulatory report, by the Directive was also anticipated reporting the supervisory authority in case of realization of previously defined events (regulations within the clause 35 and 53 of the Directive) and mandatory reporting of the supervisory authority in case of these authorities' requests (in accordance to regulations of the clause 35 of the Directive).

\section{Implications to risk governance}

\section{Own risk and solvency assessment}

A special significance within the request of the second pillar Solvency II is a request that every insurance and reinsurance company within the risk management system must implement own evaluation of risk and solvency. For indicating the own assessment of risk and solvency uses a widely accepted abbreviation ORSA (Own Risk and Solvency Assessment). In compliance with the regulations of the clause 45 of the text Solvency II, this assessment should comprise at least: a) total needs for solvency provision, taking into consideration a specific risk profile, approved limits of tolerance to risk and business strategy of insurance underwriters or reinsurance underwriters, b) continuous adjustment to the capital requirements and requests which refer to the technical reserves, and c) assessment of significance for aberration of a concrete insurance underwriter or reinsurance underwriter's risk profile from assumptions which make a base of a solvent capital requirement. The own assessment of risk and solvency 
requires implementation of adequate processes for identification and quantifying of risk. It is especially important from agricultural producers' point of view, in regard to peculiarities of agricultural production and all the risks that it entails. Also is necessary that insurance underwriters and reinsurance underwriters make an integral part of business strategy of their own risk assessment and solvency, and to apply it continuously in strategic decision-making. The assessment must be implemented without delay in case of changing the total risk profile of an insurance underwriter or reinsurance underwriter. The obligation of an insurance underwriter/reinsurance underwriter is to inform the supervisory authorities on the results of implemented risk and solvency assessment, in compliance with the regulations of the clause 35 of the Directive.

If own risk of catastrophic damages has not been assessed adequately in insurance and reinsurance companies, the occurrence of these damages can have very negative consequences to the solvency level or even lead to the solvency loss. In these conditions inevitably come to a direct income reduction, and thereby also to decrease of a legally legitimated capital, and often to a compulsory liquidation of financial and real property, so every liability under the insurance claims could be respected. Here is also an important an adequate assessment of operational risk, in regard to a fact that the occurrence of catastrophic damages in agriculture causes also a great number of the insurance claims, which requires increased operational readiness of insurance companies. Exactly due to this fact, theoreticians and practitioners, often put a question of involving the state in insurance and reinsurance activities in circumstances of increased probability of the catastrophic damages occurrences (in agricultural production). Some consider that there is necessary the state to be interfered in the process of insurance and reinsurance, they even consider it is justified also the request of the insurance companies for such intervention, some others completely deny this intervention justification. Experiences in past ten years show that the role of the state has become necessary in regard to catastrophic amount of damages, especially in agricultural production, and which cannot be absorbed by the insurance and reinsurance market. The quality assessments of this kind of risks determine some other thesis, that dividing risk and/or export by a stop loss method provides to an insurance underwriter to settle damage without the state's support. The state is left to combine by itself the infrastructure insurance (or alone bears the risk and damage), while an agricultural or other insured person cannot insure.

\section{Risk transfer in terms of Solvency II}

The results of the fifth quantitative study of Solvency II Directive impact to the insurance companies business show a significant increase of necessary capital amount. It is expected, taking into consideration that determination of quantitative claims bases on a need to provide capital for cover of all risks, not exclusive focusing to the insurance risk. It remains an open question how much will cost the insurance, for example in agriculture, where damages are caused successively, a technical result is low and dispersion requires also a premium division. If agro-business does not fall into a high-profitable activity, but it endures a high share of sociality, expensive risk insurance with a high degree of risk is heavily endured by its balance. Although the results of this study (EIOPA, 2011) point out that, in regard to the current state, by implementation of Solvency II can be expected for the entire insurance 
sector a decrease of capital surplus for around 121 milliards euro and increase of the claimed capital for ensuring the solvent capital requirement for around 320 milliards USD, there can be expected decrease of solvency ratio from $310 \%$ of realized within the regime of Solvency I to $165 \%$. So, Solvency II, if the insurance sector is observed as a whole, will cause increase of necessary capital, which will cause an increased need for all reduction mechanisms of a regulatory claimed capital, and which will particularly manifest in case of smaller and specialized insurance companies, due to the limited possibilities of risk diversification. A special significance will have mechanisms of risk transfer, primarily reinsurance, but also the alternative mechanisms.

Reinsurance, as insurance of the insurance, had a key significance in providing additional capacity for acceptance of insurable catastrophic risks, with an emphasis on the risks due to meteorological disturbance, especially if takes into consideration that it is about the international character businesses, which implicates to a fact that the cover does not limit only to the available capacity of insurance and reinsurance market within the state (Njegomir, 2008). However, lately the capacity of the entire world reinsurance market had become limited and insufficient in complete claims settlement of the insurance companies for the risk transfer. The alternative solutions appear which enable transfer of the insurance risk, like flood, for example. Such risks as the credits for construction of agro-facilities, mechanization, and new plantations have been activated by damage occurred in a main activity, by flooding a basic resource in form of sown areas. Traditionally present relation, an insured personan insurance underwriter-a reinsurance underwriter, increasingly changes its form, so the traditional demarcation line between an insurance underwriter, a reinsurance underwriter and a capital market is becoming less significant.

A current application of the alternative mechanisms of the insurance risk transfer is relatively limited in comparison to the reinsurance, primarily due to inadequate regulatory treatment. However, Solvency II Directive endeavours to give priority to economic essence over the form, which will provide the application of all forms of risk management and will implicitly provide a faster development of the alternative mechanisms of insurable risks transfer. That is to say, in the clause 101 of the Directive (Directive 2009/138/EC) was stated an extraordinary broad interpretation of the risk transfer mechanisms, which recognize in calculation of capital claims in the following way: ,,in the calculation of the solvent capital requirement, the insurance and reinsurance companies should take into consideration an effect of the risk reduction techniques, taking care that a credit risk and other risks which result from using such techniques, must be adequately reflected in the solvent capital requirement." Thereby, by the clause 13 of the Directive is specified that, under the techniques of the risk reduction are implied, ,all techniques which provide to the insurance and reinsurance companies to transfer a part or all risks to other subjects“". The only inevitable for different forms of the risk transfer to be treated on the same basis as the traditional reinsurance is that the insurance companies quantify a real contribution of different instruments to the material risk reduction. Therefore is needed a precise recognition and objective reporting (third pillar) on a preventive performance, as well as the quality and a size of the preventive investments (e.g. in anti-hail rockets), which makes 
the insurance purpose objective and justifies its price. By equal recognition and treatment of all mechanisms of the risk transfer - reinsurance, hedging and securitization, requesting from an insurance underwriter only a proof on their real contribution to the risk reduction, Solvency II framework will, unlike Solvency I, within which, in reduction of the capital requirements recognizes just reinsurance as a form of the risk reduction, will give a boost to the insurance underwriters for optimization of the risk reduction means and development of the alternative mechanisms of the risk transfer, as it is securitization.

\section{Implications to investment activities}

The traditional basic role of the insurance companies is providing the insured persons' safety from harmful consequences of the insurable risks realization. However, thanks to specificities of the insurance activities, which implies the existence of time gap between the moment of a premium payment and the moment of insurance indemnity, if comes to its realization, the insurance companies form significant insurance reserves which enable to show on the financial markets as the institutional investors (Tepavac, 2009).

The previous regulatory framework of solvency in the EU, as well as the solvency regulations outside the member-countries, including also the regulation in Serbia, had no significant impact to the investments. That is to say, the investment risk has not been taken into consideration in determination of the required capital for ensuring the solvency, but has been considered solely in the context of regulating the technical reserves means investments. The Solvency II will enable clearing away the noticed imperfections of the existing regulatory rules, primarily in domain of the risk cover during determination of the required capital amount. In regard to significant amount of assets in an investment portfolio of the insurance companies, as well as a fact that they become more and more significant institutional investors, including this risk will have significant implications to determination of the required capital amount. Investing in agricultural production along with the adequate risk assessment of production and along with use of the adequate preventive, there can be positively affected to determination of the required capital. Potentially the most important influence of a new regulatory framework Solvency II will be in domain of including all the risks, i.e. not only the insurance risk but also market and investment risk, credit and operational risk in determination of the required capital amount. By including an investment risk in determination of an insurance underwriter's capital adequacy determination Solvency II will unavoidably have the influence to the investment activities of the insurance and reinsurance companies. By this opens a space for more significant investment in agricultural production. Taking into consideration the investment risk will affect the insurance underwriters to place the available assets of technical reserves more cautious, which will imply placement in less risky financial instruments, as bonds and avoiding the risky financial instruments, as shares, or will have to possess the additional capital, in a way to support the investment risk. Especially stressed impact of investment risk will be in domain of long-term character insurance, like the investments in agricultural production, life insurance and liability insurance. The investment risk impact is especially emphasized taking into consideration that it had represented proportionally the biggest risk component in applying a standard formula in calculation of the solvent capital claim within the fifth quantitative study (EIOPA, 2011). 
The market value of assets and liabilities will represent a base in determination of solvency position, which will implicate a need for having an adequate capital amount, which will reflect short-term changes in evaluation of assets positions value. All previously stated implicate that Solvency II will change a focus of the insurance companies from long-term to short-term incomes (MSRE and Oliver Wyman, 2010), which will inevitably cause a need for change in the investment placement structure. The change of valuation of assets and liabilities position from the accounting to the market value, as well as a need for allocation of capital to cover a short-term variability in the market value of some placements, will inevitably lead to preorientation of the insurance companies investment strategies, which will consequentially cause changes in supply and demand for some financial instruments (Fitch Ratings, 2011). The direction of change, in any case, will depend on the existing structure of an insurance underwriter's investment portfolio, as well as of the level of the financial markets development.

\section{Implications to other business activities}

The Solvency II will cause the changes regarding the risk reduction, which will lead to the income reduction or to a need for increasing the costs of complementary capital obtaining. Besides the costs of the complementary capital obtaining or application of measures which will have similar negative effects to profitability, the insurance and reinsurance underwriters will inevitably have also increased costs directly connected to adjustment to the requirements of Solvency II. It is about the costs which include development of internal models, human and material resources necessary for own and capital risk assessment, for the need of increased volume and quality of reporting the supervisory authorities and disclosure of information to the public.

A need for the complementary capital, due to increasing catastrophic damages, will inevitably encourage also the activities of managers and acquisition, i.e. merging and annexing the insurance and reinsurance companies in that way will increase the capacities for paying great damages, predominantly in agriculture because of the climatic disturbances and the environment changes (Njegomir et al., 2013). The initiators of these activities will be primarily small insurance and reinsurance underwriters with limited possibilities of the complementary capital obtaining. The activities of managers and acquisitions are more certain in non-life insurances, in regard that the potential effects of diversification are more expressed in case of property insurances and liability insurances. By the fifth quantitative study was determined that the effects of diversification can be significant and to reduce a necessary amount of capital for obtaining the regulatory claimed solvency, even for $25 \%$ $35 \%$. The evaluation is that a composite insurance underwriter will have for about one third more benefits from diversification in regard to the specialized insurance underwriters, i.e. the insurance underwriters which deal only with non-life or only with life insurances (MSRE and Oliver Wyman, 2010). All previously mentioned will surely be an additional motive for consolidation on the insurance and reinsurance market, but also redefining a relation to the insured persons by types of insurance, especially for the activities which change human health, nutrition, temperature, the amount of shallow water, and which damages are no longer a series of small losses, but consolidated (as well as the capital). 
Besides the changes regarding the consolidation, on the insurance market can be expected also the internal organizational changes. It is possible to expect that the insurance underwriter will aspire to realize the diversification effects aiming to optimize the capital structure, efficiency of capital use with the ultimate goal of realizing the greater economic effects for owners of capital. As a consequence of these efforts is possible development of an internal reinsurance, which will enable the transfer of all risks within the group to one internal reinsurance underwriter. On the other hand, it is possible to expect the consolidation within the insurance groups, by consolidation of branches into one legal entity, by which can realize, besides the capital, significant strategic and operational advantages. The other internal organizational changes are possible, too. The European Commission (EC, 2010) research, implemented in the period between November 2010 and January 2011, showed the expectation that the insurance companies of an independent company within the group will transfer in branches aimed to reduce administrative costs and capital costs. The reduction of these costs is possible by recognizing the greater diversification effects, simpler treatment of reinsurance within the group and the existence of small-scale restrictions on the transfer of capital.

Some types of the insurance cover can become non-profitable for the insurance underwriters, thanks to the higher capital claims, and thereby new regulatory rules can cause their disappearance in regard that the insurance underwriters can stop selling or significantly reduce it. The insurance of crops and fruits and animal insurance fall in very risky insurances in which the insurance companies realize negative results, especially when it is about Serbia, where damage ration in these types of insurance is almost $100 \%$. If we add to such high ratio relatively high administration and acquisition costs, a combined ratio probably surpasses $100 \%$, which implicates that collected premium in these insurances is not sufficient for the insurance indemnity and other costs. This would have resulted with non-insurability of some risks, which would be harmful for individual agricultural producers, insurance companies, but for the economy and the entire society, too. Taking it into consideration, it is reasonable to expect that the insurance companies will find methods for overcoming the increased capital claims.

\section{Conclusion}

The existing regulatory framework of solvency on the European Union level, very similar to the regulatory framework in Serbia, is in a phase of explicit changes towards implementation to principle-based regulations. Although a precise date has not been yet determined, by repeatedly changed, current speculations are that the directive implementation will start in 2015 or 2016; there is expected that Solvency II, as a new frame of insurance companies solvency regulations on the EU level will have significant consequences to governance and business of the insurance companies, which are facing a new challenge of taking positions towards the insurance in agriculture with insufficiently developed consciousness on possibilities of insurance, inadequate price and increasing need for a capital, due to increasing risks and costs of supervision of this type of risk. 
Regulation based on applying the principles orders increasing responsibility to regulated subject regarding an adequate governance system, as well as carrying out all business activities in a way to provide an adequate size of capital, taking into consideration peculiarities of some insurance underwriters' business activities, the regulation subjects. Reorientation of insurance companies business will be necessary especially in domain of risk and capital governance, as key determinants of long-term success of the insurance companies. Also, a total governance system, especially in the field of risk and capital governance, will become much more transparent and directed to establishment of management culture, which will provide a solvent and profitable business with adaptability to new situations on the market, instead of the previous orientation to coordination to the regulatory requirements.

Taking into consideration all characteristics and implications of new regulatory framework we consider that, in spite of some costs and efforts, aiming to adjust to changes, its application will result with significant increase of an insured person's safety. New regulatory rules will mean a better certainty for agricultural producers regarding damage reimburse in case of production risks. However, a threat of new regulatory rules is present, owing to higher risk and high combined ratio in insurance of agriculture, that it can impose to agricultural producers higher insurance premiums or even to limit services availability of the insurance cover. We think that, by limiting supply of insurance services would be counter-productive, as in economic sense for the agricultural producers and insurance companies, as well as in a broader, social sense, in regard to agriculture development, such important activity, would be substantially limited and in disadvantage position. In that sense, we think that the insurance companies will find ways for adequate management of agricultural risks, as well as investing a part of assets from the technical reserves cover in agriculture and different preventive interventions, in own interest and in interest of agricultural producers, but also by relaxing a broader social community with enforced liabilities, accepted by it, because no one can, due to market under development and consciousness on insurance.

\section{Literature}

1. Consultation on the Level 2 implementing measures for Directive 2009/138/EC on the taking-up and pursuit of the business of Insurance and Reinsurance (Solvency II), DG Internal Market and Services, Insurance and Pensions Unit, European Commission, Brussels, November 2010.

2. Directive 2009/138/EC of The European Parliament and of the Council of 25 November 2009 on the taking-up and pursuit of the business of Insurance and Reinsurance (Solvency II), Official Journal of the European Union L 335, Brussels, 17.12.2009.

3. EC (2003): Design of a future prudential supervisory system in the EU-Recommendations by the Commission Services, MARKT/2509/03-EN, European Commission, Internal Market DG, Brussels, 3 March 2003.

4. EC and KPMG (2012): Study into the methodologies to assess the overall financial position of an insurance undertaking from the perspective of prudential supervision, European Commission and KPMG, Contract no: ETD/2000/BS-3001/C/45, May 2002. 
5. EC (2006): Amended framework for consultation on Solvency II, MARKT/2515/06, European Commission, Internal Market DG, Brussels, April 2006.

6. EIOPA (2011): Report of the fifth Quantitative Impact Study (QIS5) for Solvency II, European Insurance and Occupational Pensions Authority, Frankfurt.

7. FitchRatings (2011): Solvency II Set to Reshape Asset Allocation and Capital Markets, Insurance Rating Group Special Report, FitchRatings, New York.

8. Jorion, P. (2001): Value at Risk: The New Benchmark for Managing Financial Risk, McGraw- Hill, New York.

9. MSRE and Wyman, O. (2010): Solvency 2: Quantitative \& Strategic Impact: The Tide is Going Out, Morgan Stanley Research Europe and Oliver Wyman, September 22, 2010.

10. Njegomir, V. (2006): Specifičnosti upravljanja kapitalom u osiguravajućim društvima, Računovodstvo, Vol. 50, No. 7-8, str. 59-68.

11. Njegomir, V. (2008): Uloga tržišta kapitala u upravljanju rizikom osiguranja, Industrija, Vol. 36, No. 4, Ekonomski institute, Beograd, str. 95-118.

12. Njegomir, V. (2009): Solvency II direktiva i njen uticaj na upravljanje rizikom $u$ osiguravajućim društvima, Finansije, Vol. 64, No. 1-6, str. 272-306.

13. Njegomir, V. (2011a): Sistemski rizik i osiguranje, Računovodstvo, Vol. 55, No. 1-2, Beograd, str. 89-114.

14. Njegomir, V. (2011b): Osiguranje, Ortomedics book, Novi Sad.

15. Njegomir, V. (2011c): Osiguranje i reosiguranje: tradicionalni $i$ alternativni pristupi, Tectus, Zagreb.

16. Njegomir, V., Tepavac, R., Počuča, M. (2013): Kapaciteti sektora osiguranja i reosiguranja:implikacije katastrofalnih šteta, Medjunarodna politika, vol. 64., no. 1149, pp. 137-156, Institut za međunarodnu politiku i privredu, Beograd.

17. PricewaterhouseCoopers (2010): The forgotten pillar: Time to bring disclosure onto the radar, PricewaterhouseCoopers, London.

18. PricewaterhouseCoopers (2011): Risk of Delay: Getting Pillar 3 on Track, PricewaterhouseCoopers, London.

19. Tepavac, R. (2009): Institucionalni investitori na finansijskom tržištu, Filip Višnjić, Beograd. 